\title{
Preparation of Diffusion Couples for Irradiation and High Temperature Testing of Representative TRISO PyC/SiC
}

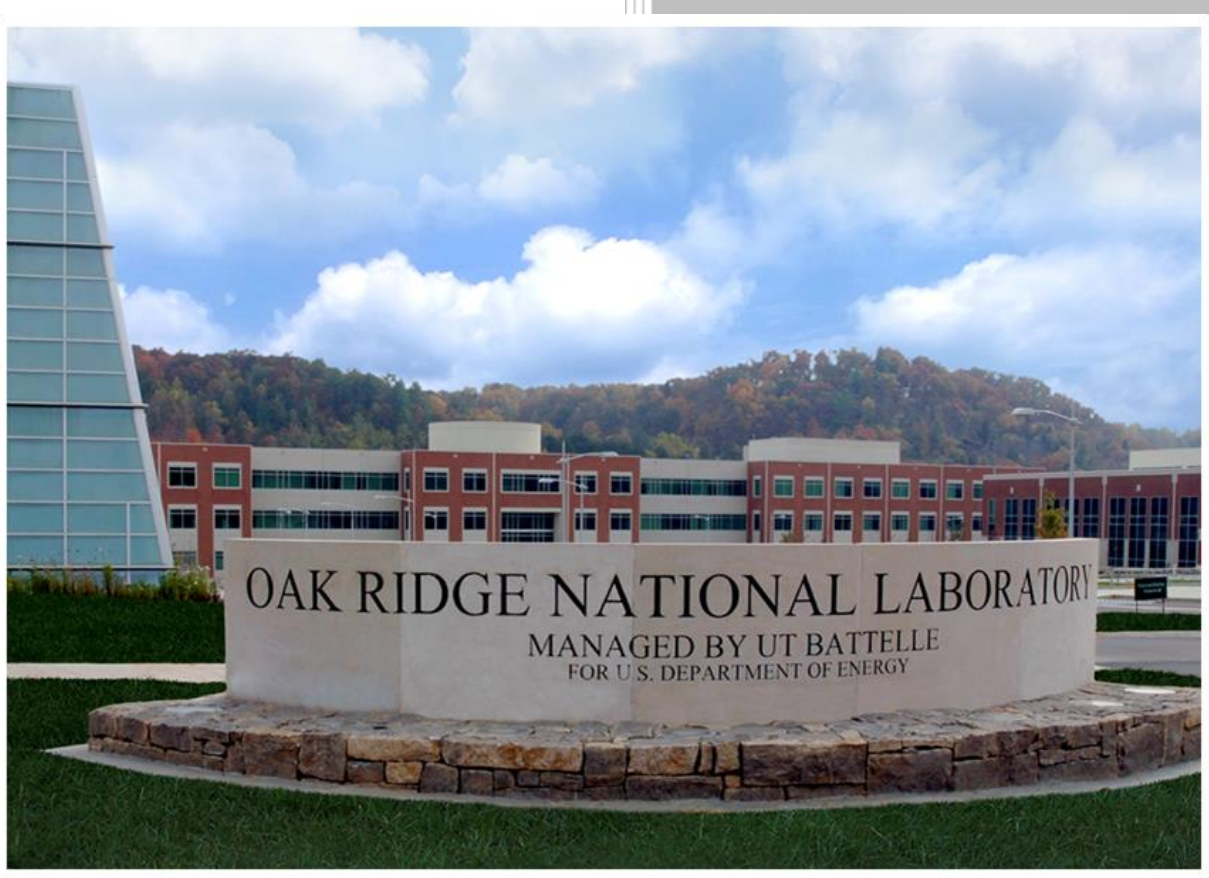

Approved for public release. Distribution is unlimited.
Tyler J. Gerczak Anne A. Campbell Xunxiang $\mathrm{Hu}$ John D. Hunn Brian C. Jolly Rachel L. Seibert Austin T. Schumacher

September 2018 


\title{
DOCUMENT AVAILABILITY
}

Reports produced after January 1, 1996, are generally available free via US Department of Energy (DOE) SciTech Connect.

Website http://www.osti.gov/scitech/

Reports produced before January 1,1996, may be purchased by members of the public from the following source:

\author{
National Technical Information Service \\ 5285 Port Royal Road \\ Springfield, VA 22161 \\ Telephone 703-605-6000 (1-800-553-6847) \\ TDD 703-487-4639 \\ Fax 703-605-6900 \\ E-mail info@ntis.gov \\ Website http://www.ntis.gov/help/ordermethods.aspx
}

Reports are available to DOE employees, DOE contractors, Energy Technology Data Exchange representatives, and International Nuclear Information System representatives from the following source:

Office of Scientific and Technical Information

PO Box 62

Oak Ridge, TN 37831

Telephone 865-576-8401

Fax 865-576-5728

E-mail reports@osti.gov

Website http://www.osti.gov/contact.html

This report was prepared as an account of work sponsored by an agency of the United States Government. Neither the United States Government nor any agency thereof, nor any of their employees, makes any warranty, express or implied, or assumes any legal liability or responsibility for the accuracy, completeness, or usefulness of any information, apparatus, product, or process disclosed, or represents that its use would not infringe privately owned rights. Reference herein to any specific commercial product, process, or service by trade name, trademark, manufacturer, or otherwise, does not necessarily constitute or imply its endorsement, recommendation, or favoring by the United States Government or any agency thereof. The views and opinions of authors expressed herein do not necessarily state or reflect those of the United States Government or any agency thereof. 


\title{
PREPARATION OF DIFFUSION COUPLES FOR IRRADIATION AND HIGH TEMPERATURE TESTING OF REPRESENTATIVE TRISO PYC/SIC
}

\author{
Tyler J. Gerczak \\ Anne A. Campbell \\ Xunxiang $\mathrm{Hu}$ \\ John D. Hunn \\ Brian C. Jolly \\ Rachel L. Seibert \\ Austin T. Schumacher
}

Date Published: September 2018

Prepared by

OAK RIDGE NATIONAL LABORATORY

Oak Ridge, TN 37831-6283

managed by

UT-BATTELLE, LLC

for the

US DEPARTMENT OF ENERGY

under contract DE-AC05-00OR22725 



\section{CONTENTS}

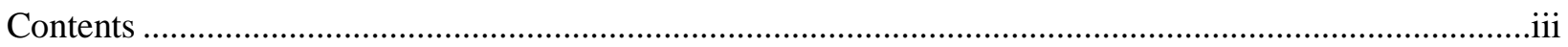

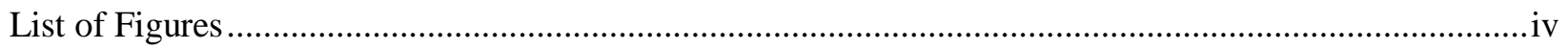

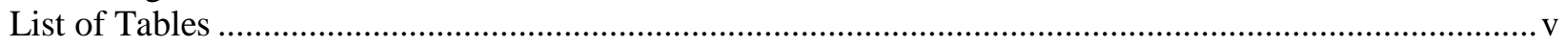

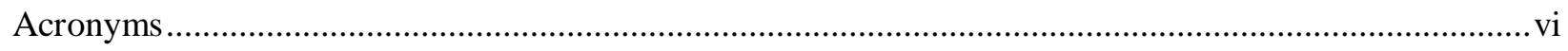

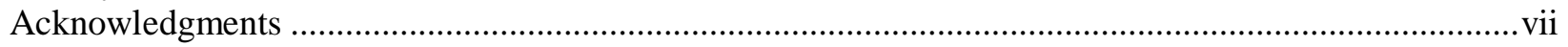

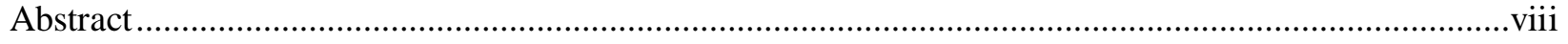

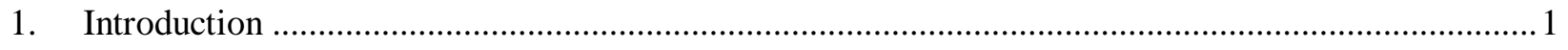

1.1 Motivation: Fission Product Release from TRISO Fuel........................................................ 1

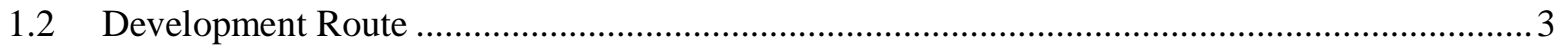

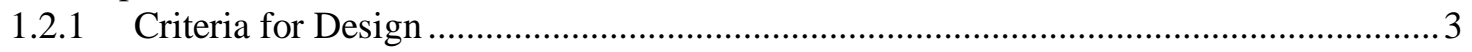

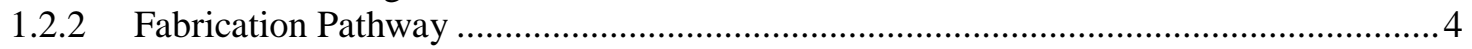

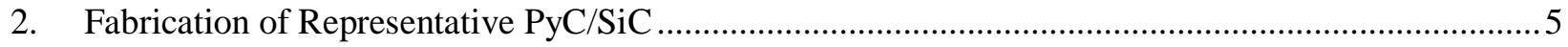

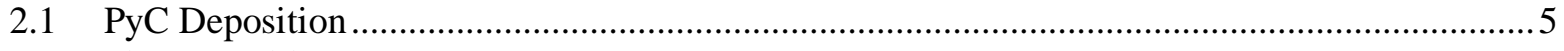

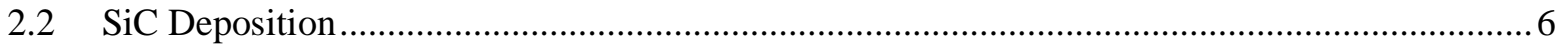

3. Development of Isolated Diffuison Couple System ……..............................................................

3.1 Delivery of Diffusing Species: Ion Implantation ...........................................................

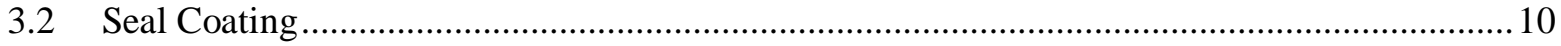

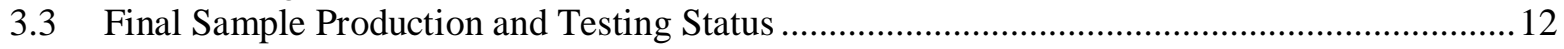

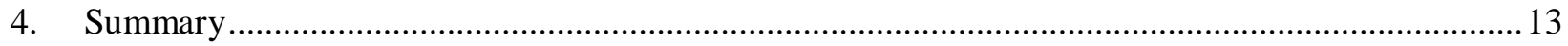

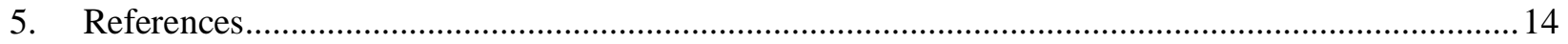




\section{LIST OF FIGURES}

Figure 1. AGR-1 particle cross-section and x-ray radiography of a prismatic compact from AGR-2 ......... 1

Figure 2. Schematic of diffusion couple fabrication process [33] ........................................................ 4

Figure 3. Photograph of sectioned PyC/SiC/S-PyC samples (left) and a cross-section optical image of a

$\mathrm{SiC}$ seal coated sample (right).

Figure 4. PyC sink/float density as a function of deposition temperature [33] ...................................... 6

Figure 5. Inverse pole figure showing the local variation in the $\mathrm{SiC}$ microstructure of the Baseline variant

[33]

Figure 6. Scanning electron microscope, backscatter electron image of the $\mathrm{SiC}$ layer for a pure $\mathrm{H}_{2}$

fluidized SiC showing a disruption in the SiC coating layer [31].

Figure 7. Inverse pole figure showing the local variation in the $\mathrm{SiC}$ microstructure of the $\mathrm{SiC}$ variant [33].

.

Figure 8. Optical images of MS-SiC/PyC cross-sections deposited at $700{ }^{\circ} \mathrm{C}$ and $900{ }^{\circ} \mathrm{C}$ [32] .............. 11

Figure 9. GD-OES depth profile of multilayer $\mathrm{SiC}$ seal coating on silver implanted Baseline

$\mathrm{PyC} / \mathrm{SiC} / \mathrm{S}-\mathrm{PyC}$ diffusion couple. Time correlates to depth [28]................................................ 12

Figure 10. Seal-coated PyC/SiC/S-PyC samples as-fabricated (top) and after thermal exposure at $1700{ }^{\circ} \mathrm{C}$,

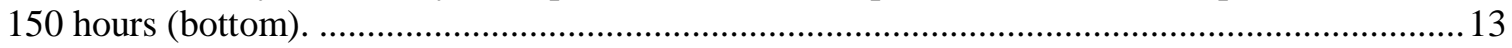




\section{LIST OF TABLES}

Table 1. Test matrix for planar diffusion couple experiment [28]. 3

Table 2. Properties of AGR-2 UCO fuel variant and the three planar diffusion couple variants [33]......... 4

Table 3. Comparison of implantation dose to estimated dose required to meet EOL inventory [33].........10

Table 4. Multilayer SiC seal coating conditions [28]. 


\section{ACRONYMS}

AGR Advanced Gas Reactor (Fuel Development and Qualification Program)

AGR-1 First AGR fuel irradiation experiment

AGR-2 Second AGR fuel irradiation experiment

$\mathrm{C}_{2} \mathrm{H}_{2} \quad$ Acetylene

$\mathrm{C}_{3} \mathrm{H}_{6} \quad$ Propylene

CGF Coating gas fraction

dpa Displacements per atom

EBSD Electron backscatter diffraction

EOL End-of-life

FB-CVD Fluidized bed chemical vapor deposition

GD-OES Glow discharge optical emission spectroscopy

HFIR

HTGR High temperature gas-cooled reactor

IPyC Inner pyrolytic carbon

MS Methylsilane

MTS Methyltrichlorosilane

OPyC Outer pyrolytic carbon

PyC Pyrolytic carbon or pyrocarbon

S-PyC Support pyrocarbon

sccm Standard cubic centimeters per minute

$\mathrm{SiC} \quad$ Silicon carbide (TRISO layer)

TGF Total gas flow

TRISO Tristructural-isotropic (coated particles)

UCO mixed uranium carbide/uranium oxide (kernels)

$\mathrm{UO}_{2} \quad$ Uranium dioxide 


\section{ACKNOWLEDGMENTS}

This research is being performed using funding received from the DOE Office of Nuclear Energy's Nuclear Energy University Program through a joint NEET/NEUP R\&D with NSUF access award (Project 16-10764). Significant support for this work was provided by Victoria Cox, Travis Dixon, John Dyer, and Tom Geer. 


\begin{abstract}
Understanding the release of fission products from intact tristructural-isotropic (TRISO) coated particle fuel during normal and off-normal service is necessary to ensuring safe and efficient reactor operation. Planar diffusion couples have been fabricated to determine the diffusion kinetics of select fission product species $(\mathrm{Ag}, \mathrm{Ag}+\mathrm{Pd}, \mathrm{Eu}$, and $\mathrm{Sr})$ in pyrocarbon $(\mathrm{PyC})$ and silicon carbide $(\mathrm{SiC})$ materials which are representative of TRISO fuel. Obtaining accurate diffusion coefficients for these systems in representative materials will allow for higher fidelity inputs for fuel performance models. Three different diffusion couple variants have been produced which include a Baseline, $\mathrm{PyC}$, and $\mathrm{SiC}$ variant. The Baseline variant serves as an example of representative $\mathrm{PyC}$ and $\mathrm{SiC}$ layers as the layer properties mimic those found in TRISO fuel from the second Advanced Gas Reactor Fuel Qualification and Development Program. The $\mathrm{PyC}$ and $\mathrm{SiC}$ variants include variation in the respective layer properties to understand the impact of PyC density and $\mathrm{SiC}$ grain size on fission product diffusion. The diffusion couples were designed to allow for exploration of neutron irradiation on diffusion reflecting in reactor behavior as well as high temperature thermal diffusion reflecting diffusive transport during off-normal conditions. The methodology for selecting the diffusion couple design, refinement of the individual variant layer properties, and the complete process for diffusion couple construction are summarized in this report.
\end{abstract}


ORNL/TM-2018/1012-R0 


\section{INTRODUCTION}

\subsection{MOTIVATION: FISSION PRODUCT RELEASE FROM TRISO FUEL}

Tristructural-isotropic (TRISO) coated particle fuel is being considered for multiple advanced reactor concepts. The fuel concept was first identified for application in high temperature gas-cooled reactors (HTGR). The development of TRISO fuel has centered around HTGR deployment [1,2] but recently the concept has been considered as a fuel form for molten salt reactors [3] and as an accident tolerant fuel concept in light water reactors [4].

The design of the TRISO fuel particle consists of a fissile fuel kernel surrounded by four successive layers of low-density carbon buffer, pyrolytic carbon (PyC), silicon carbide ( $\mathrm{SiC})$, and a final PyC layer, Figure 1. The kernel material for TRISO fuel produced for the Advanced Gas Reactor Fuel Qualification and Development Program (AGR) is a two phase uranium dioxide $\left(\mathrm{UO}_{2}\right)$ and uranium carbide material (UCO), however, $\mathrm{UO}_{2}$ fuel has also been investigated [2,5]. The first pyrolytic carbon layer is termed the "inner" pyrolytic carbon (IPyC), while the second layer is termed the "outer" pyrolytic carbon (OPyC). The individual particles are overcoated with a graphite and resin binder and compacted into a final fuel geometry. Typical final geometries include pebble or prismatic concepts. During service each layer in the TRISO construction provides a specific purpose. In particular, the IPyC layer provides a barrier to the release of gaseous fission products and $\mathrm{SiC}$ layer provides a barrier to the release of metallic fission products not retained in the kernel. Figure 1 shows a cross-section of an as-fabricated TRISO particle from the first AGR irradiation (AGR-1) along with an X-ray radiograph of a prismatic compact from the second AGR irradiation (AGR-2) showing the distribution of particles within the prismatic compact.

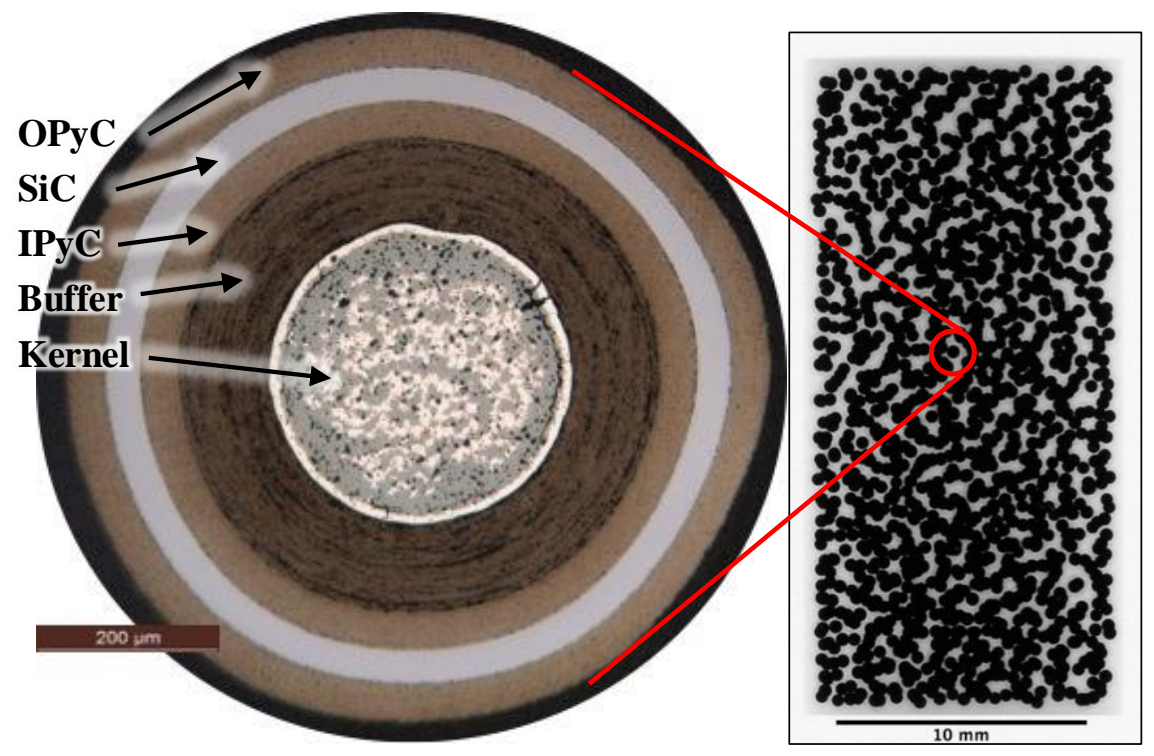

Figure 1. AGR-1 particle cross-section and x-ray radiography of a prismatic compact from AGR-2.

The TRISO fuel design is defined by its all refractory construction which enables high temperature operation and passive safety benefits in HTGR reactor designs. At elevated temperatures, associated with both normal operation and accident and margin conditions, diffusive release of select fission products from the TRISO fuel system becomes relevant $[6,7]$. An understanding of the release kinetics and factors 
impacting release are required to provide fuel performance models with accurate data to ensure high fidelity simulations and safe and efficient reactor operation.

Historically, ${ }^{110 \mathrm{~m}} \mathrm{Ag}$ release has garnered much attention due to its notable release relative to other fission products and lack of consensus regarding the release mechanism [8-10]. Concerning silver release, there is a reported discrepancy between the diffusion kinetics reported from in-pile release experiments, out-of-pile release experiments, surrogate experiments, and computational modeling efforts [11-26]. The reported in-pile release is more rapid than out-of-pile release and surrogate experiments. This variation highlights the motivation to understand the impact of neutron irradiation on silver transport.

Microstructural effects have also been observed to impact release, necessitating the investigation of diffusion in representative materials to yield accurate diffusion kinetics. Another factor that is postulated to impact silver release is the complexity of the diffusion system, where it is speculated that palladium may increase silver transport through the system $[11,12]$. At elevated irradiation temperatures and during safety testing at margin temperatures $\left(1800{ }^{\circ} \mathrm{C}\right),{ }^{90} \mathrm{Sr}$ and ${ }^{154} \mathrm{Eu}$ have also been observed to be released [6]. Here, ${ }^{90} \mathrm{Sr}$ is a biologically relevant isotope relevant to reactor safety while ${ }^{154} \mathrm{Eu}$ is a radiologically relevant isotope for qualifying fuel performance. Limited insight exists concerning the diffusion kinetics of strontium and europium in TRISO materials relative to silver [1].

To determine diffusion coefficients of silver, strontium and europium in representative TRISO materials a planar diffusion couple system was developed. The diffusion couple design includes both $\mathrm{PyC}$ and $\mathrm{SiC}$ materials as the release pathway from TRISO fuel is across the IPyC into the SiC layer. The nature of the $\mathrm{IPyC} / \mathrm{SiC}$ interface is speculated to impact behavior of fission products interacting with the SiC layer [27]. The diffusion couples are fabricated using the same fluidized bed chemical vapor deposition (FB-CVD) system used to produce TRISO coated particle fuel for the AGR-1 irradiation. Thus, the $\mathrm{PyC} / \mathrm{SiC}$ construction represents the integral release pathway through representative $\mathrm{PyC} / \mathrm{SiC}$ materials to understand transport.

Three different materials systems are being investigated to understand the impact of different layer properties on diffusive transport of four separate fission product systems ( $\mathrm{Ag}, \mathrm{Ag}+\mathrm{Pd}, \mathrm{Eu}$, and $\mathrm{Sr})$. The different material systems include a Baseline variant, $\mathrm{PyC}$ variant, and $\mathrm{SiC}$ variant. The Baseline sample is intended to be representative of the AGR-2 TRISO fuel material system. The PyC variant focuses on a higher density $\mathrm{PyC}$ layer to modify the $\mathrm{PyC} / \mathrm{SiC}$ interface while the $\mathrm{SiC}$ variant includes a larger grain size microstructure. The planar design was sought to utilize depth profiling techniques necessary for diffusion analysis.

The test matrix for the diffusion couple study is shown in Table 1. The test conditions cover the three sample variants and four fission product systems. The exposure conditions are meant to investigate diffusion under irradiation and diffusion at temperatures representing accident and margin conditions. To understand the influence of neutron irradiation on diffusion, select samples have been irradiated at elevated temperature in hydraulic "rabbit" capsules in the High Flux Isotope Reactor (HFIR) to two different irradiation doses defined by the displacements per atom (dpa) of the $\mathrm{SiC}$ layer (Section 3.3). A thermal equivalent sample will be compared to the neutron irradiated sample to determine the impact of neutron irradiation on diffusion and solubility of the specific fission product system. The results of this study aim to provide diffusion coefficients in a baseline $\mathrm{PyC} / \mathrm{SiC}$ material system while also identifying how various layer properties and neutron irradiation impacts diffusion in materials representative of the TRISO system. 
Table 1. Test matrix for planar diffusion couple experiment [28].

\begin{tabular}{|c|c|}
\hline Condition & Sample Conditions \\
\hline $\begin{array}{l}\text { Neutron Irradiation } \\
\left(0.5 \mathrm{dpa}, 1100 \pm 50^{\circ} \mathrm{C}\right)\end{array}$ & \multirow{4}{*}{$\begin{array}{l}\text { Baseline: } \mathrm{Ag}, \mathrm{Ag}+\mathrm{Pd}, \mathrm{Eu}, \mathrm{Sr} \\
\text { Commercial-SiC: } \mathrm{Ag} \\
\text { SiC Variant: } \mathrm{Ag}, \mathrm{Eu}, \mathrm{Sr}\end{array}$} \\
\hline $\begin{array}{l}\text { Neutron Irradiation } \\
\left(1.0 \mathrm{dpa}, 1100 \pm 50^{\circ} \mathrm{C}\right)\end{array}$ & \\
\hline $\begin{array}{c}\text { Thermal Diffusion } \\
\text { (Temperature \& time equivalent of } 0.5 \mathrm{dpa} \text { ) }\end{array}$ & \\
\hline $\begin{array}{c}\text { Thermal Diffusion } \\
\text { (Temperature \& time equivalent of } 1.0 \text { capsule) }\end{array}$ & \\
\hline $\begin{array}{l}\text { High-Temperature Thermal Diffusion } \\
\quad\left(1500{ }^{\circ} \mathrm{C} \text {, two conditions }\right)\end{array}$ & $\begin{array}{c}\text { Baseline: } \mathrm{Ag}, \mathrm{Ag}+\mathrm{Pd}, \mathrm{Eu}, \mathrm{Sr} \\
\text { PyC Variant: } \mathrm{Ag}, \mathrm{Ag}+\mathrm{Pd} \\
\text { SiC Variant: } \mathrm{Ag}, \mathrm{Eu} \mathrm{Sr}\end{array}$ \\
\hline $\begin{array}{l}\text { High-Temperature Thermal Diffusion } \\
\qquad\left(1600^{\circ} \mathrm{C} \text {, two conditions }\right)\end{array}$ & $\begin{array}{c}\text { Baseline: } \mathrm{Ag}, \mathrm{Ag}+\mathrm{Pd}, \mathrm{Eu}, \mathrm{Sr} \\
\text { PyC Variant: } \mathrm{Ag}, \mathrm{Ag}+\mathrm{Pd} \\
\text { SiC Variant: } \mathrm{Ag}, \mathrm{Eu} \mathrm{Sr}\end{array}$ \\
\hline $\begin{array}{l}\text { High-Temperature Thermal Diffusion } \\
\left(1700^{\circ} \mathrm{C} \text {, two conditions }\right)\end{array}$ & $\begin{array}{c}\text { Baseline: } \mathrm{Ag}, \mathrm{Ag}+\mathrm{Pd}, \mathrm{Eu}, \mathrm{Sr} \\
\text { PyC Variant: } \mathrm{Ag}, \mathrm{Ag}+\mathrm{Pd} \\
\text { SiC Variant: } \mathrm{Ag}, \mathrm{Eu} \mathrm{Sr}\end{array}$ \\
\hline
\end{tabular}

*Excess samples will go to NEUP archive.

${ }^{\wedge}$ The estimated neutron irradiation temperature is based on capsule design thermal analysis [29].

This report is a summary of the diffusion couple development process. In depth description of the process summarized here has been captured in a series of quarterly reports which serve to document the development process [28,30-33].

\subsection{DEVELOPMENT ROUTE}

\subsubsection{Criteria for Design}

The criteria for the diffusion couple design focused on the layer properties and system requirements. One such design requirement was a diffusion couple system which facilitated application of depth profiling techniques. This is critical for the determination of concentration profiles in the $\mathrm{PyC}$ and $\mathrm{SiC}$ layers for diffusion kinetics analysis. The sample geometry and size must be such that a FB-CVD reactor can be used to produce samples with representative PyC and $\mathrm{SiC}$ microstructures. The system should be closed and simulate the pathway for release from TRISO fuel, that is, diffusion through PyC to SiC. The closed system also limits loss of the diffusing "fission product" species to the environment. The concentration of "fission product" species should represent that which is present in the TRISO fuel system. The diffusion couple design must also fit within the constraints of the irradiation capsule design which limits the size and geometry of the samples. The irradiation capsule design occurred in parallel with the diffusion couple development [29].

Targeted layer properties for the $\mathrm{PyC}$ and $\mathrm{SiC}$ layers were identified based on the AGR program experience. Table 2 identifies the properties targeted for the unique layers for each variant. The Baseline properties focused on representing UCO kernel fuel from the AGR-2. This fuel represents TRISO particles produced at an industrial-scale to which there is extensive associated PIE efforts. The critical design requirements for the diffusion couple are $\mathrm{SiC}$ microstructure and $\mathrm{PyC}$ density and the baseline variant is required to fall within the measured grain size for AGR-2 UCO TRISO [34]. The PyC variant focused on a higher density PyC relative to the Baseline variant. The higher density $\mathrm{PyC}$ is intended to modify the PyC/SiC interface to limit interfacial stitching which is speculated to impact the interaction of fission products with the $\mathrm{SiC}$ layer. For the $\mathrm{PyC}$ variant, the $\mathrm{SiC}$ microstructure was constant while a PyC 
density target of $>1.95 \mathrm{~g} / \mathrm{cm}^{3}$ was identified. The $\mathrm{SiC}$ variant required a larger $\mathrm{SiC}$ grain size compared to the Baseline variant. Grain size has shown to impact release during safety testing at $1800{ }^{\circ} \mathrm{C}$ for ${ }^{110 \mathrm{~m}} \mathrm{Ag}$ and ${ }^{154} \mathrm{Eu}$ during AGR-1 safety testing, where larger-grained $\mathrm{SiC}$ displayed a lower effective diffusion coefficient relative to finer-grained $\mathrm{SiC}[6,34]$. The $\mathrm{SiC}$ variant grain size targets represent the grain size from AGR-1 large grained variants and provides a comparison for the impact on microstructure on fission product diffusion.

Table 2. Properties of AGR-2 UCO fuel variant and the three planar diffusion couple variants [33].

\begin{tabular}{cccc} 
& \multicolumn{2}{c}{ PyC Density } & \multicolumn{2}{c}{ SiC Grain Size } \\
\cline { 2 - 4 } & $\left(\mathbf{g} / \mathbf{c m}^{\mathbf{3}}\right)$ & (major axis, $\boldsymbol{\mu m})$ & (minor axis, $\boldsymbol{\mu m})$ \\
\hline AGR-2 UCO $^{*}[5,34]$ & $1.890 \pm 0.011$ & $0.89 \pm 0.14$ & $0.35 \pm 0.05$ \\
\hline Baseline & $1.85-1.95$ & $0.75-1.03$ & $0.30-0.40$ \\
\hline PyC & $>1.95$ & $0.75-1.03$ & $0.30-0.40$ \\
\hline $\mathrm{SiC}$ & $1.85-1.95$ & $2.10-2.70$ & $0.50-0.80$ \\
\hline
\end{tabular}

*values from [34] are reported as mean \pm standard deviation

\subsubsection{Fabrication Pathway}

Based on the criteria for the diffusion couple design, a planar geometry diffusion couple was deemed to meet this requirement while still facilitating layer deposition using a FB-CVD system to produce representative PyC and SiC material. The layered carbon-SiC planar diffusion couple concept was first demonstrated by Dwaraknath and Was to study diffusion in commercially available SiC material $[35,36]$. The production route identified involves the deposition of three successive layers on a sapphire disk, Figure 2. The first layer is the representative PyC layer followed by the representative $\mathrm{SiC}$ layer with properties identified in Table 2. The final layer is a support PyC (S-PyC) layer which provides structural stability to the diffusion couple. The properties (density or microstructure) of the S-PyC were not optimized. The targeted layer thicknesses were 8-12 $\mu \mathrm{m}, 35-50 \mu \mathrm{m}$ and $>60 \mu \mathrm{m}$ for the PyC, SiC and S-PyC layers respectively [30].

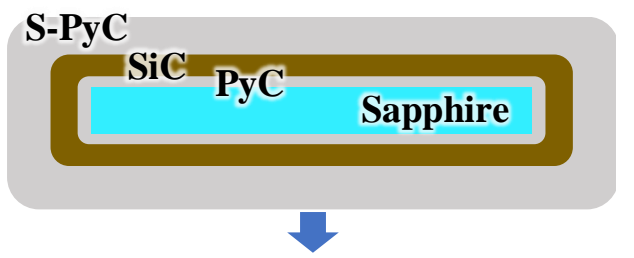

\section{Each layer is deposited successively in the} FB-CVD coater

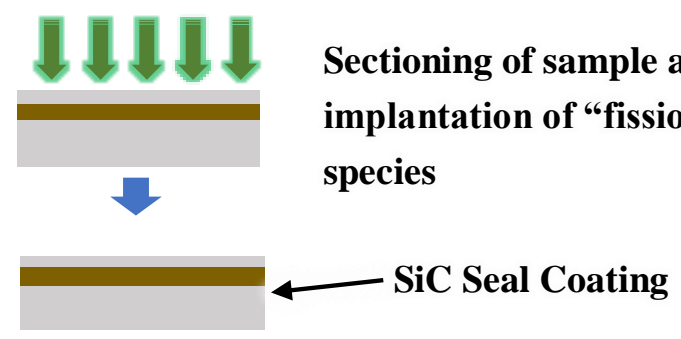

Figure 2. Schematic of diffusion couple fabrication process [33].

Fluidization was ideal on 9-mm diameter sapphire disks - the largest diameter sapphire disk tested [30]. This was also ideal as it yielded the largest sample area post-deposition. After deposition, the layered structures (PyC/SiC/S-PyC) were sectioned to nominally $3 \times 4-5 \mathrm{~mm}$ samples, Figure 3 . The difference in coefficient of thermal expansion between the deposition layers and the sapphire disk led to easy 
liberation of the layered structure sample from the disk. Up to four samples per disk were able to be obtained. The $3 \times 4-5 \mathrm{~mm}$ sample geometry was identified as the sample dimensions were constrained by the irradiation capsule design which has a limited inner volume. The "thin" sample design was also considered ideal to limit thermal gradients across the diffusion couple [29]. The simulated fission product species were introduced to the PyC layer via ion implantation to ensure the typical $\mathrm{PyC}$ to $\mathrm{SiC}$ diffusion pathway for the diffusing species of interest. A subsequent high temperature seal coating of SiC deposited in the same FB-CVD system was utilized to establish a closed system for diffusion analysis. Figure 3 shows a typical cross-section of the $\mathrm{PyC} / \mathrm{SiC} / \mathrm{S}-\mathrm{PyC}$ structure with final $\mathrm{SiC}$ seal coating.

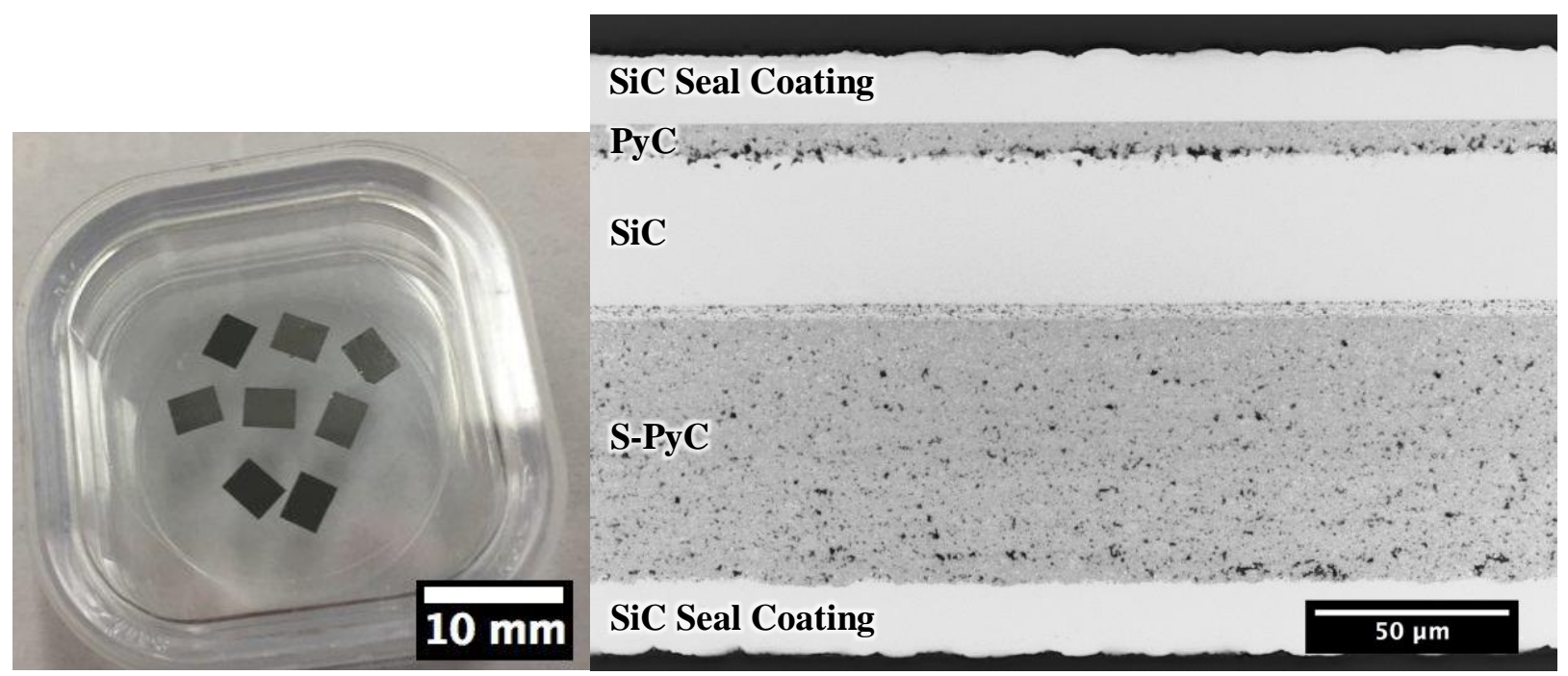

Figure 3. Photograph of sectioned PyC/SiC/S-PyC samples (left) and a cross-section optical image of a SiC seal coated sample (right).

\section{FABRICATION OF REPRESENTATIVE PYC/SIC}

The FB-CVD deposition process was based on established procedures (AGR-Surrogate-Coat-SOP-01) utilized for the fabrication of AGR-1 TRISO particles. Process development was required to establish appropriate deposition conditions due to the change in substrate geometry. The sapphire disks were fluidized along with $102 \mathrm{~g}$ of $400 \mu \mathrm{m} \mathrm{ZrO}$ media to establish a fluidized bed under flowing Ar or a blend of $\mathrm{Ar}$ and $\mathrm{H}_{2}$. The layers were deposited in succession while remaining at elevated temperature by cycling temperatures and precursors gases. Primary factors which impact the resultant properties include total gas flow (TGF), coating gas fraction (CGF), fluidization gas, and deposition temperature. These variables were manipulated to produce $\mathrm{PyC}$ and $\mathrm{SiC}$ layers with tailored properties to satisfy the criteria targeted in Table 2 [30].

\subsection{PYC DEPOSITION}

The deposition of the PyC and S-PyC was accomplished using a gas mixture of acetylene $\left(\mathrm{C}_{2} \mathrm{H}_{2}\right)$, propylene $\left(\mathrm{C}_{3} \mathrm{H}_{6}\right)$ and $\mathrm{Ar}$. An in depth discussion of the PyC deposition effort is found in the reports by Gerczak et al. [30,31]. Initial scoping was performed to optimize the system TGF and CGF for the PyC deposition. Final depositions were carried out with TGF of 6000 standard cubic centimeters per min (sccm) with a CGF of 0.3. The CGF is defined here as the precursor gas flow divided by the TGF. The precursor gas flows for $\mathrm{C}_{2} \mathrm{H}_{2}$ and $\mathrm{C}_{3} \mathrm{H}_{6}$ were $973 \mathrm{sccm}$ and $827 \mathrm{sccm}$ respectively for all $\mathrm{PyC}$ depositions with the difference being $\operatorname{Ar}(4200 \mathrm{sccm})$. 
The PyC density was manipulated by varying the deposition temperature from $1270{ }^{\circ} \mathrm{C}$ to $1390{ }^{\circ} \mathrm{C}$. Interrupted coating runs were performed to isolate the deposited $\mathrm{PyC}$ layer allowing direct measurement of the PyC density. The density of the $\mathrm{PyC}$ was measured via sink/float density using a linear-gradient density column. This method was employed to measure the density of PyC during TRISO fuel development efforts for the AGR program [37]. Figure 4 shows sink/float density of the PyC layer as a function of deposition temperature. The range in deposition conditions resulted in measured PyC densities from $1.754 \pm 0.038-2.022 \pm 0.004 \mathrm{~g} / \mathrm{cm}^{3}$, where the \pm value represents one standard deviation from the mean. The range in obtained $\mathrm{PyC}$ density satisfied the targeted requirements for all diffusion couple variants listed in Table 2. For the Baseline and $\mathrm{SiC}$ Variants the targeted PyC density was $1.90 \mathrm{~g} / \mathrm{cm}^{3}$ this was satisfied by deposition at $1350{ }^{\circ} \mathrm{C}$. The $\mathrm{PyC}$ Variant required a density $>1.95 \mathrm{~g} / \mathrm{cm}^{3}$, however, to ensure sufficient structural variation a density of $\sim 2.00 \mathrm{~g} / \mathrm{cm}^{3}$ was sought. This was satisfied by deposition at $1300{ }^{\circ} \mathrm{C}$. These $\mathrm{PyC}$ deposition conditions were utilized for the fabrication of the full diffusion couple layered structures (PyC/SiC/S-PyC) [31,33].

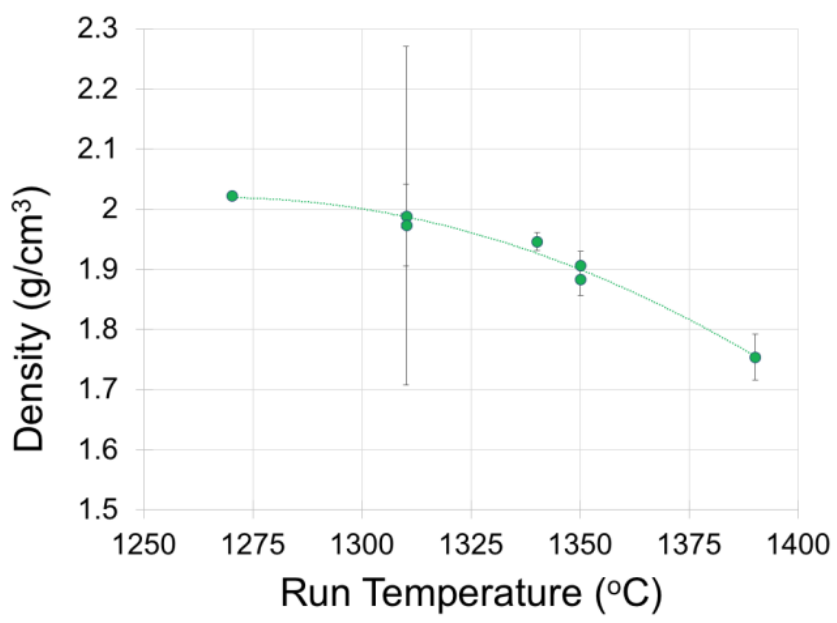

Figure 4. PyC sink/float density as a function of deposition temperature [33].

The deposition conditions for the S-PyC layer varied relative to the PyC layer. The layer properties were not optimized as the $\mathrm{S}-\mathrm{PyC}$ was deposited to provide structural support. The $\mathrm{S}-\mathrm{PyC}$ was deposited at elevated TGF relative to the PyC layer. The higher TGF was required to sufficiently fluidization the system due to the increase in total surface area during the deposition of a thick S-PyC layer compared to the PyC layer. The CGF was 0.3 which was consistent with the PyC deposition, however, the precursor gas flows for $\mathrm{C}_{2} \mathrm{H}_{2}$ and $\mathrm{C}_{3} \mathrm{H}_{6}$ were $1460 \mathrm{sccm}$ and $1240 \mathrm{sccm}$ respectively for all S-PyC depositions with the remainder being $\operatorname{Ar}(6300 \mathrm{sccm})$. These conditions yielded a S-PyC thickness of $68-85 \mu \mathrm{m}$ which was sufficient to provide structural stability to the layered diffusion couple samples [30].

\subsection{SIC DEPOSITION}

Development of the $\mathrm{SiC}$ layer was completed on full coating samples. Initial deposition conditions were derived from previous experience coating TRISO fuel particles on identical coating furnaces [30,31]. Typical TRISO SiC layers are deposited using a precursor gas of methyltrichlorosilane (MTS) in $\mathrm{Ar}+\mathrm{H}_{2}$ or pure $\mathrm{H}_{2}$ fluidizing gas. Prior efforts have shown temperature and fluidization gas (Ar versus $\left.\mathrm{Ar}+\mathrm{H}_{2}\right)$ have a significant impact on the resultant $\mathrm{SiC}$ layer microstructure [34,38]. The addition of Ar impacts the fluidization and renucleation yielding a finer microstructure than depositions using pure $\mathrm{H}_{2}$ fluidization gas [38]. A total of thirteen coating development runs were undertaken to obtain the SiC layers with the targeted properties (Table 2) for all three variants of interest [31]. 
Grain size and shape was the established metric for acceptance. Grain size is reported as major and minor axis length to capture the non-equiaxed nature of the FB-CVD deposited $\mathrm{SiC}$ microstructure. Grain size and shape was measured using electron backscatter diffraction (EBSD) techniques based on previously established techniques and reporting [34]. Details of the EBSD acquisition are discussed in depth in the report by Gerczak et al. [31].

The SiC layer for the Baseline and PyC Variants were deposited using MTS in $\mathrm{Ar}+\mathrm{H}_{2}$ at $1425^{\circ} \mathrm{C}$ to target the fine-grained $\mathrm{SiC}$ microstructure obtained during deposition of AGR-1 Variant 3 and AGR-2 UCO TRISO fuel [38,39]. Initial SiC depositions focused on obtaining optimal fluidization conditions. Significant porosity was observed in the initial runs and the CGF was adjusted to obtain high quality SiC layers [31]. The CGF was increased from 0.015 to 0.023 over a series of deposition runs. The higher CGF yielded $\mathrm{SiC}$ with limited porosity.

The depositions at $1425^{\circ} \mathrm{C}$ resulted in a $\mathrm{SiC}$ grain size below of the targeted criteria; average major axis of $0.67 \pm 0.13 \mu \mathrm{m}$ and minor axis of $0.25 \pm 0.04 \mu \mathrm{m}$. In subsequent runs the temperature was increased in 25 ${ }^{\circ} \mathrm{C}$ increments to impact the final grain size. The optimal deposition conditions for the Baseline and PyC Variants were identified as $\sim 200$ min deposition at $1450{ }^{\circ} \mathrm{C}, 3250 \mathrm{sccm}$ Ar, $3250 \mathrm{sccm} \mathrm{H}_{2}$ with a coating gas fraction of 0.021 resulting in $\sim 180 \mathrm{~g}$ of MTS being consumed. These conditions yielded a SiC microstructure with an average major axis of $0.85 \pm 0.33 \mu \mathrm{m}$ and minor axis of $0.30 \pm 0.08 \mu \mathrm{m}$ which satisfied the targeted grain size criteria (Table 2). Figure 5 shows an inverse pole figure of the local grain orientation of the $\mathrm{SiC}$ layer visualizing the microstructure. The deposition at $1475^{\circ} \mathrm{C}$ resulted in an average grain size just outside the targeted criteria; average major axis of $1.03 \pm 0.38 \mu \mathrm{m}$ and minor axis of $0.41 \pm 0.11 \mu \mathrm{m}$. The \pm represents one standard deviation from the calculated mean [31].

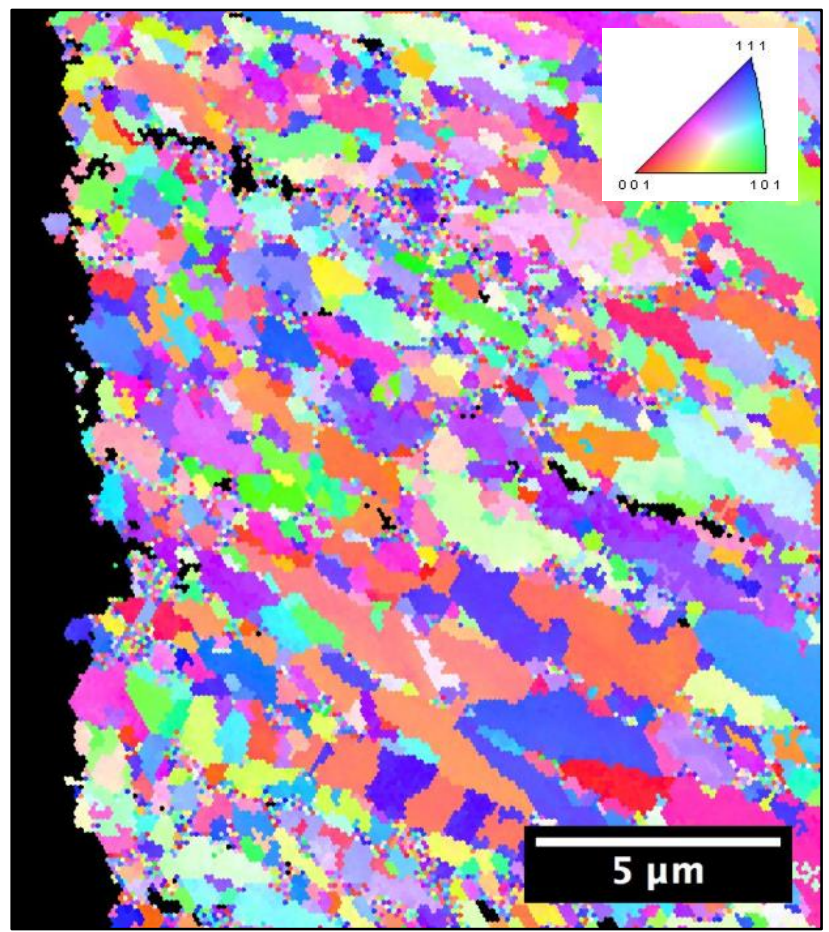

Figure 5. Inverse pole figure showing local variation in the $\mathrm{SiC}$ microstructure of the Baseline variant [33].

Prior experience shows deposition in pure $\mathrm{H}_{2}$ yields large grained $\mathrm{SiC}$ relative to $\mathrm{Ar}+\mathrm{H}_{2}$ fluidized depositions [38]. To target the large grain size sought for the $\mathrm{SiC}$ Variant the $\mathrm{SiC}$ was initially deposited in pure $\mathrm{H}_{2}$. The change in fluidization gas required an increase in TGF from $7000 \mathrm{sccm}$ to $13000 \mathrm{sccm}$ to 
maintain fluidization over the course of the deposition [31]. The resultant $\mathrm{SiC}$ displayed an increase grain size, however, the $\mathrm{SiC}$ layer was prone to disruptions leading to an irregular $\mathrm{SiC}$ microstructure. An example of the $\mathrm{SiC}$ microstructure with a layer disruption is shown in Figure 6. The presence of disruptions is atypical of coated particle fuel depositions and is likely resultant of the planar geometry.

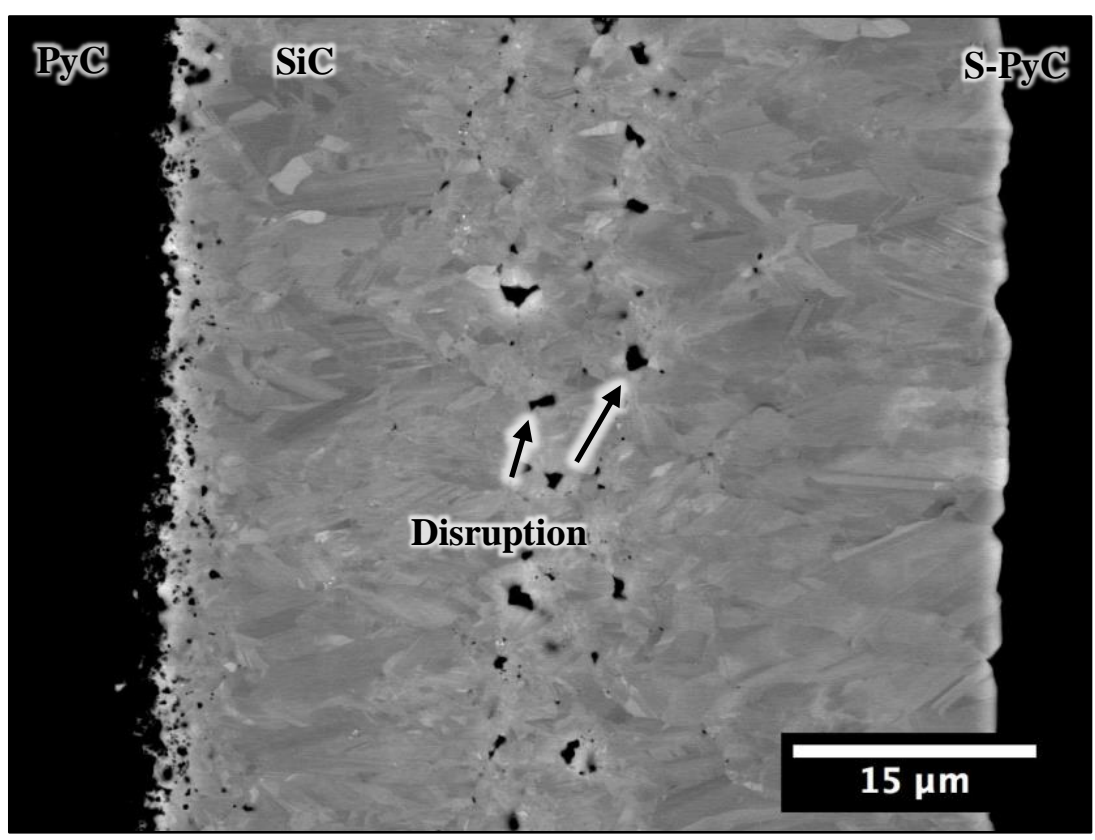

Figure 6. Scanning electron microscope, backscatter electron image of the $\mathrm{SiC}$ layer for a pure $\mathrm{H}_{2}$ fluidized $\mathrm{SiC}$ showing a disruption in the $\mathrm{SiC}$ coating layer [31].

The $\mathrm{Ar}+\mathrm{H}_{2}$ fluidized depositions did not display any layer disruptions. The series of coating runs with incrementally higher temperatures $\left(1425-1475^{\circ} \mathrm{C}\right)$ confirmed the grain size could be manipulated as a function of temperature. Attempts to achieve the targeted grain size for the $\mathrm{SiC}$ variant at higher temperature depositions $\left(>1475^{\circ} \mathrm{C}\right)$ in a $\mathrm{Ar}+\mathrm{H}_{2}$ fluidized bed were successful in achieving larger-grained $\mathrm{SiC}$ with no observable disruptions [31]. The optimal deposition conditions for the $\mathrm{SiC}$ variant was identified as $200 \mathrm{~min}$ deposition at $1550{ }^{\circ} \mathrm{C}, 3250 \mathrm{sccm} \mathrm{Ar}, 3250 \mathrm{sccm} \mathrm{H}_{2}$ with a coating gas fraction of 0.021 resulting in $\sim 180 \mathrm{~g}$ of MTS being consumed. This deposition was $100{ }^{\circ} \mathrm{C}$ greater than the Baseline and $\mathrm{PyC}$ variant depositions. These conditions yielded a $\mathrm{SiC}$ microstructure with an average major axis of $2.50 \pm 1.01 \mu \mathrm{m}$ and minor axis of $0.53 \pm 0.14 \mu \mathrm{m}$ which satisfied the targeted grain size criteria [31]. Figure 7 shows an inverse pole figure of the local grain orientation of the $\mathrm{SiC}$ layer to visualize the microstructure. Comparisons of Figure 5 and Figure 7 show the qualitative difference in obtained SiC microstructures. 


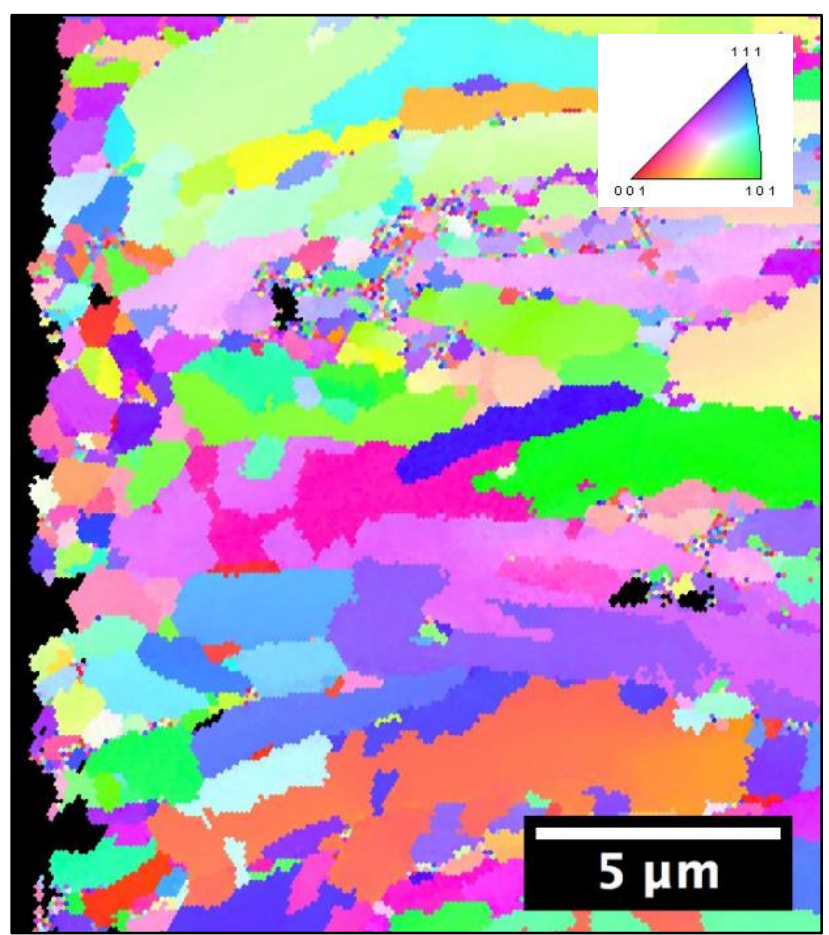

Figure 7. Inverse pole figure showing local variation in the $\mathrm{SiC}$ microstructure of the $\mathrm{SiC}$ variant [33].

\section{DEVELOPMENT OF ISOLATED DIFFUISON COUPLE SYSTEM}

\subsection{DELIVERY OF DIFFUSING SPECIES: ION IMPLANTATION}

Ion implantation was identified as an ideal approach to introduce the simulated fission product species into the PyC layer in the PyC/SiC/S-PyC diffusion couple samples. Direct implantation into the PyC layer ensures the diffusion pathway follows $\mathrm{PyC} \rightarrow \mathrm{SiC}$ for the $\mathrm{SiC}$ layer of interest. Ion implantation was conducted at the University of Michigan's Michigan Ion Beam Laboratory through Nuclear Science User Facility access. The implantations were conducted on a 400-kV Ion Implanter (NEC, Middleton, WI, USA). Four different systems were implanted: $\mathrm{Ag}, \mathrm{Ag}+\mathrm{Pd}, \mathrm{Eu}$, and $\mathrm{Sr}$ (Table 1) [32]. The implanted dose was based on the calculated concentration of each species in an AGR-1 TRISO fuel particle at end-of-life (EOL) [33]. The total planned dose was adjusted for the difference in total PyC/SiC surface area between a typical TRISO particle and the planar diffusion couple design. Table 3 lists the implanted fluence for each system [33]. Variation between the targeted fluence and actual fluence exists due to experimental constraints associated with attainable beam current for each specie. In particular the targeted strontium fluence was not attainable due to low achievable beam current leading to a lower than EOL dose [32]. An elevated silver dose was sought due to identified challenges in retaining silver during dose both during development of the diffusion couples design and in prior experiments reported in the literature $[15,35]$. For silver, an approximately $2 \times$ higher dose was implanted. 
Table 3. Comparison of implantation dose to estimated dose required to meet EOL inventory [33].

\begin{tabular}{ccc}
\hline & Actual Fluence* & Est. fluence to match EOL inventory \\
\hline Fission Product System & Ions/cm & Ions/cm $^{\mathbf{2}}$ \\
\hline $\mathrm{Ag}$ & $8.4 \times 10^{16}$ & $4.0 \times 10^{16}$ \\
\hline $\mathrm{Ag}+\mathrm{Pd}^{\#}$ & $8.4 \times 10^{16} / 8.4 \times 10^{16}$ & $4.0 \times 10^{16} / 7.4 \times 10^{17}$ \\
\hline $\mathrm{Eu}$ & $5.7 \times 10^{16}$ & $7.6 \times 10^{16}$ \\
\hline $\mathrm{Sr}$ & $5.7 \times 10^{16}$ & $1.3 \times 10^{18}$ \\
\hline
\end{tabular}

*All implantations were conducted at $400 \mathrm{kV}$ at room temperature.

${ }^{\wedge}$ Considers all isotopes generated through fission [40].

"Implantations were conducted in succession.

\subsection{SEAL COATING}

The final step in the diffusion couple fabrication process was the development of a high temperature seal coating of the PyC/SiC/S-PyC diffusion couple. The seal-coating was implemented to produce an isolated system to retain the implanted dose during high temperature neutron irradiation and thermal exposure. The seal coating development required significant development effort which primarily focused on the retention of mobile implanted species. The retention of silver was the primary point of focus of the development process as it is the most mobile of the implanted species in PyC [1].

An in depth description of the seal-coating development can be found in the prior reports by Gerczak et al. [28,30-33]. The seal coating deposition varied from standard $\mathrm{SiC}$ deposition. A primary variation is that the seal coating was deposited on the $3 \times 4-5 \mathrm{~mm}$, PyC/SiC/S-PyC samples and not sapphire disks. The fluidization media consisted of buffer coated $\mathrm{ZrO}_{2}$ beads instead of $\mathrm{ZrO}_{2}$ beads to reduce the mechanical impact on the samples and the samples were inserted into the fluidized bed at temperature. Initial efforts focused on utilizing a MTS-derived SiC layer similar to the SiC layer in the PyC/SiC/S-PyC structure. The MTS-derived SiC was considered ideal as it has demonstrated high temperature stability and radiation tolerance and limited variation in structure relative to the tailored $\mathrm{SiC}$ layer. However, the deposition rate was not rapid enough to retain the implanted dose at $1425^{\circ} \mathrm{C}$ due to silver diffusion in the PyC [31]. The retained dose was measured via depth profiling using glow discharge optical emission spectroscopy (GD-OES) [32].

Alternative "low" temperature seal coating was sought to produce an isolated diffusion system. The FB-CVD reactor has demonstrated the ability to produce $\mathrm{SiC}$ below $900^{\circ} \mathrm{C}$ using a methylsilane (MS) as a precursor gas [41]. A series of depositions were pursued to develop the capability to deposit $\mathrm{SiC}$ at low temperatures and the subsequent stability of the MS-derived $\mathrm{SiC}[28,32]$. Deposition was observed at above $700{ }^{\circ} \mathrm{C}$. Figure 8 shows optical images of the cross-sections of MS-derived SiC deposited at $700{ }^{\circ} \mathrm{C}$ and $900{ }^{\circ} \mathrm{C}$ on PyC. The images show a qualitative difference in structure. Post deposition heating tests show improved thermal stability of the $\mathrm{SiC}$ layer with elevated deposition temperature with neither layer showing complete stability above $1000^{\circ} \mathrm{C}$. An inverse correlation with dose retention and deposition temperature was also observed with the lower temperature depositions retaining more of the initial implantation dose $[28,32]$. 


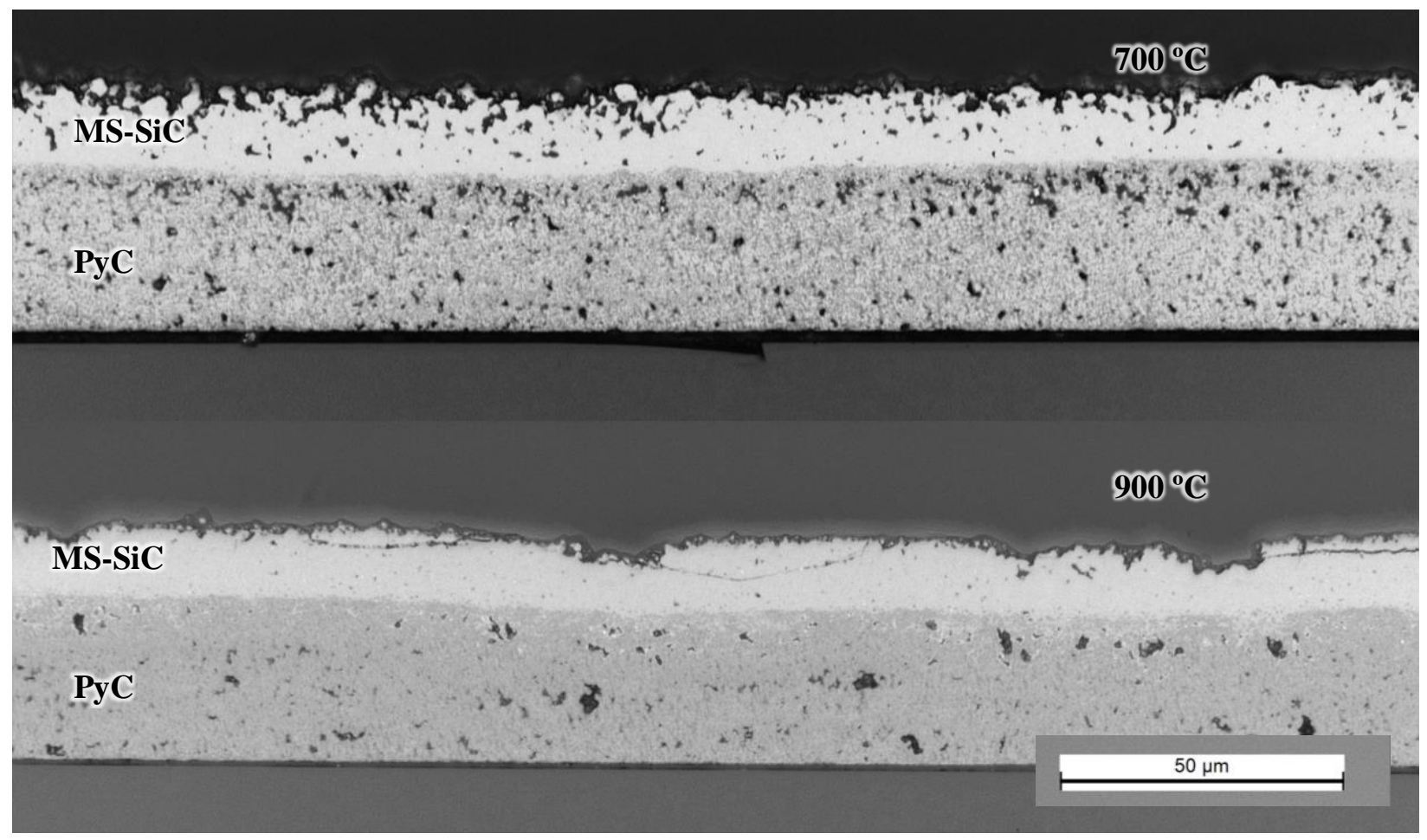

Figure 8. Optical images of MS-SiC/PyC cross-sections deposited at $700{ }^{\circ} \mathrm{C}$ and $900{ }^{\circ} \mathrm{C}[32]$.

Due to the limited robustness of the MS derived SiC at high temperatures and inverse relationship of dose retention with deposition temperature a multistep seal-coating process was developed. The final identified process involved three separate, interrupted depositions. The first two depositions were MS-derived SiC at $700{ }^{\circ} \mathrm{C}$ and $900{ }^{\circ} \mathrm{C}$, these layers provided initial barriers to loss of the implantation dose. A final MTS-derived SiC layer deposited at $1425^{\circ} \mathrm{C}$ provided high temperature stability during irradiation testing and thermal exposures [28]. The deposition conditions for the multi-step process is shown in Table 4. The retained dose after deposition is shown in Figure 9 and establishes the fabrication of an isolated system with remaining dose available for diffusion [28]. One detrimental aspect of the low temperature MS-derived SiC was the elevated solubility relative to the MTS-derived SiC, however, this aspect was considered acceptable, but must be considered when interpreting the results of eth diffusion study.

Table 4. Multilayer SiC seal coating conditions [28].

\begin{tabular}{cccccccc}
\hline $\begin{array}{c}\text { Precursor } \\
\text { Gas }\end{array}$ & $\begin{array}{c}\text { Run } \\
\text { Time } \\
(\mathbf{m i n})\end{array}$ & Temp. $\left({ }^{\circ} \mathbf{C}\right)$ & Ar & H & MS & CGF $^{\text {a }}$ & $\begin{array}{c}\text { MTS used } \\
(\mathbf{g})\end{array}$ \\
\hline MS & 45 & 700 & 6000 & - & 60 & 0.0099 & \\
\hline MS & 120 & 900 & 6000 & - & 60 & 0.0099 & \\
\hline MTS & 56 & 1425 & 3500 & 3500 & - & 0.0224 & 60 \\
\hline
\end{tabular}

${ }^{\mathrm{a}}$ CGF is coating gas fraction, all gas flow rates are in standard cubic centimeters per minute (sccm). 


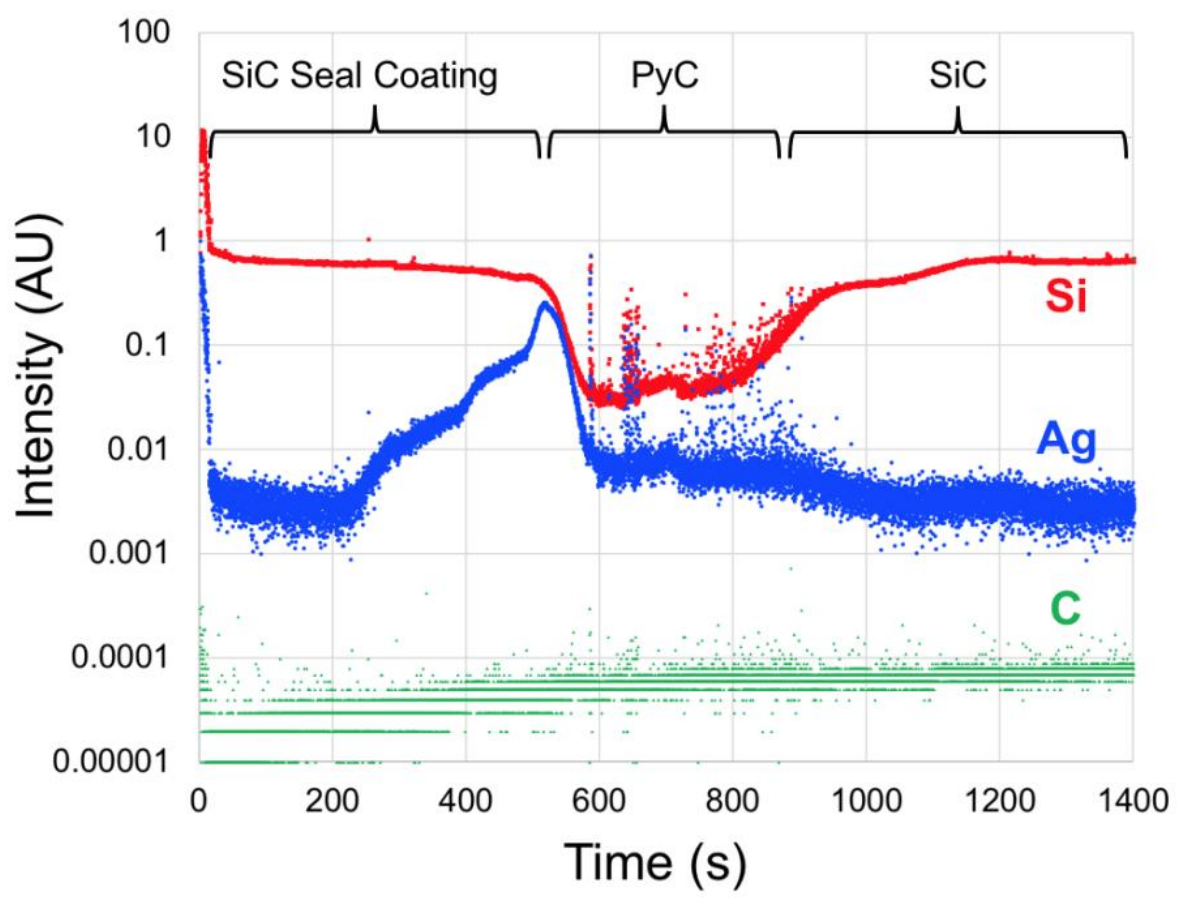

Figure 9. GD-OES depth profile of multilayer $\mathrm{SiC}$ seal coating on silver implanted Baseline PyC/SiC/S-PyC diffusion couple. Time correlates to depth [28].

\subsection{FINAL SAMPLE PRODUCTION AND TESTING STATUS}

Layered diffusion couple samples consisting of $\mathrm{PyC} / \mathrm{SiC} / \mathrm{S}-\mathrm{PyC}$ with tailored properties were produced following the deposition conditions identified for each specific variant (Baseline, $\mathrm{PyC}$, and $\mathrm{SiC}$ ) described in Section 2. Ion implantation was conducted by the University of Michigan's Michigan Ion Beam Laboratory to introduce the diffusion species and an isolated system was obtained through the development of a high temperature seal coating (Table 4). Samples have been produced to complete the test matrix identified in Table 1 including both neutron irradiation and thermal exposure samples. A total of 120 unique diffusion couples samples were produced to satisfy the test matrix.

The neutron irradiation testing has been completed. The rabbit capsule assembly was completed in June, 2018 and is outline in the report "Assembly of rabbit Capsules for Irradiation of Pyrolytic Carbon / Silicon Carbide Diffusion Couples in the High Flux Isotope Reactor - ORNL/SPR-2018/876” [42]. Two capsules were constructed for the planned 0.5 and 1.0 dpa irradiations. The capsules were subsequently inserted into HFIR cycle 481 in location B3, position 6. Capsule DC01 experienced 120 hours of total irradiation time, while Capsule DC02 experienced 263.02 hours. The capsules are currently awaiting disassembly followed by subsequent sample analysis and confirmation of irradiation conditions.

Thermal testing is ongoing in a Thermal Technology Inc. graphite element ASTRO furnace. The system is capable of exposures up to $1800^{\circ} \mathrm{C}$. The neutron equivalent samples (Table 1) will be thermally exposed upon completion of the $\mathrm{SiC}$ thermometry analysis [43]. The thermometry analysis is required to validate the capsule irradiation temperature. High temperature thermal diffusion exposures have been initiated. The first thermal exposures were tested up to $1700{ }^{\circ} \mathrm{C}$ for 150 hours. The samples maintained their integrity with no visible deterioration, Figure 10. 


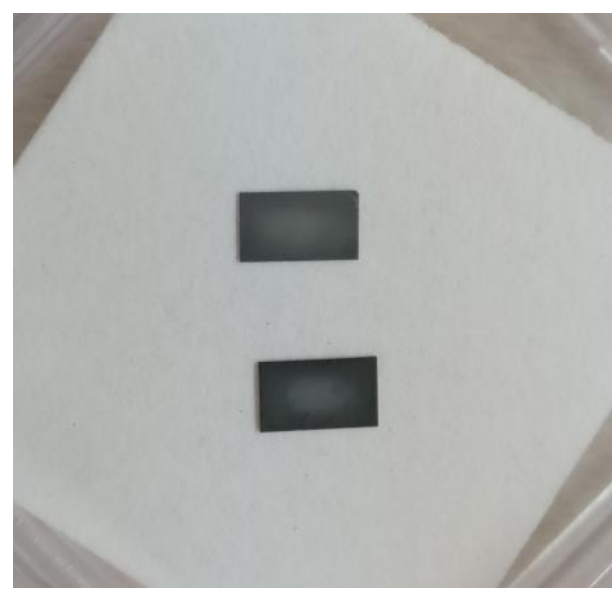

Figure 10. Seal-coated $\mathrm{PyC} / \mathrm{SiC} / \mathrm{S}-\mathrm{PyC}$ samples as-fabricated (top) and after thermal exposure at $1700{ }^{\circ} \mathrm{C}, 150$ hours (bottom).

\section{SUMMARY}

An extensive research and development effort was successfully completed to produce diffusion couples to explore diffusion of several fission product systems ( $\mathrm{Ag}, \mathrm{Ag}+\mathrm{Pd}, \mathrm{Eu}$, and $\mathrm{Sr}$ ) in representative TRISO layer materials. The final design was constrained by several experimental criteria based on observations from TRISO fuel behavior. The final design consisted of ion implanted $\mathrm{PyC} / \mathrm{SiC} / \mathrm{S}$-PyC layer structures subsequently seal coated to produce an isolated system for exposure and diffusion analysis. The Baseline variant's $\mathrm{PyC}$ and $\mathrm{SiC}$ layer properties were tailored to represent the layer properties of AGR TRISO fuel. The PyC and SiC Variants explored differences in their PyC (density) and SiC (grain size) layer properties to understand the impact of these properties on fission product diffusion. Samples have been fabricated to explore both neutron irradiation effects and high temperature thermal diffusion. Sample exposure and diffusion analysis is ongoing. 
ORNL/TM-2018/1012-R0

\section{REFERENCES}

[1] K. Verfondern, Fuel performance and fission product behaviour in gas cooled reactors, Vienna, 1997.

[2] D.A. Petti, J. Maki, J. Hunn, P. Pappano, C. Barnes, J. Saurwein, S. Nagley, J. Kendall, R. Hobbins, An Overview of the DOE Advanced Gas Reactor Fuel Development and Qualification Program, J. Mater. 62 (2006) 62-66.

[3] C.W. Forsberg, Developments in Molten Salt and Liquid-Salt-Cooled Reactors, Proc. ICAPP '06. (2006).

[4] K.A. Terrani, L.L. Snead, J.C. Gehin, Microencapsulated fuel technology for commercial light water and advanced reactor application, J. Nucl. Mater. 427 (2012) 209-224. doi:10.1016/j.jnucmat.2012.05.021.

[5] B.P. Collin, AGR-2 Irradiation Test Final As-Run Report, Idaho Falls, 2014.

[6] R.N. Morris, C.A. Baldwin, P.A. Demkowicz, J.D. Hunn, E.L. Reber, Performance of AGR-1 high-temperature reactor fuel during post-irradiation heating tests, Nucl. Eng. Des. 306 (2016) 24 35. doi:10.1016/j.nucengdes.2016.04.031.

[7] J.D. Hunn, C.A. Baldwin, F.C. Montgomery, T.J. Gerczak, R.N. Morris, G.W. Helmreich, P.A. Demkowicz, J.M. Harp, J.D. Stempien, Initial examination of fuel compacts and TRISO particles from the US AGR-2 irradiation test, Nucl. Eng. Des. 329 (2018) 89-101. doi:10.1016/j.nucengdes.2017.09.017.

[8] J.B. Malherbe, Diffusion of fission products and radiation damage in SiC, J. Phys. D. Appl. Phys. 46 (2013). doi:10.1088/0022-3727/46/47/473001.

[9] B.G. Kim, S. Yeo, Y.W. Lee, M.S. Cho, Comparison of diffusion coefficients and activation energies for ag diffusion in silicon carbide, Nucl. Eng. Technol. 47 (2015) 608-616. doi:10.1016/j.net.2015.05.004.

[10] I.J. Van Rooyen, M.L. Dunzik-Gougar, P.M. Van Rooyen, Silver (Ag) transport mechanisms in TRISO coated particles: A critical review, Nucl. Eng. Des. 271 (2014) 180-188. doi:10.1016/j.nucengdes.2013.11.029.

[11] E.J. Olivier, J.H. Neethling, The role of Pd in the transport of Ag in SiC, J. Nucl. Mater. 432 (2013) 252-260. doi:10.1016/j.jnucmat.2012.07.033.

[12] J.H. Neethling, J.H. O'Connell, E.J. Olivier, Palladium assisted silver transport in polycrystalline SiC, Nucl. Eng. Des. 251 (2012) 230-234. doi:10.1016/j.nucengdes.2011.09.064.

[13] R.E. Bullock, Fission-product release during postirradiation annealing of several types of coated fuel particles, J. Nucl. Mater. 125 (1984) 304-319. doi:10.1016/0022-3115(84)90558-0.

[14] J.J. van der Merwe, Evaluation of silver transport through SiC during the German HTR fuel program, J. Nucl. Mater. 395 (2009) 99-111. doi:10.1016/j.jnucmat.2009.09.024.

[15] T.J. Gerczak, B. Leng, K. Sridharan, J.L. Hunter, A.J. Giordani, T.R. Allen, Observations of Ag diffusion in ion implanted SiC, J. Nucl. Mater. 461 (2015). doi:10.1016/j.jnucmat.2015.03.027.

[16] B. Leng, H. Ko, T.J. Gerczak, J. Deng, A.J. Giordani, J.L. Hunter, D. Morgan, I. Szlufarska, K. Sridharan, Effect of carbon ion irradiation on Ag diffusion in SiC, J. Nucl. Mater. 471 (2016). doi:10.1016/j.jnucmat.2015.11.017.

[17] D. Shrader, S.M. Khalil, T. Gerczak, T.R. Allen, A.J. Heim, I. Szlufarska, D. Morgan, Ag diffusion in cubic silicon carbide, J. Nucl. Mater. 408 (2011). doi:10.1016/j.jnucmat.2010.10.088.

[18] S. Khalil, N. Swaminathan, D. Shrader, A.J. Heim, D.D. Morgan, I. Szlufarska, Diffusion of Ag along $\Sigma 3$ grain boundaries in 3C-SiC, Phys. Rev. B - Condens. Matter Mater. Phys. 84 (2011) 113. doi:10.1103/PhysRevB.84.214104.

[19] H. Nabielek, P.E. Brown, P. Offermann, Silver Release from Coated Particle Fuel, Nucl. Technol. 35 (1977) 483-493. doi:10.13182/NT35-483.

[20] E. Friedland, J.B. Malherbe, N.G. van der Berg, T. Hlatshwayo, A.J. Botha, E. Wendler, W. Wesch, Study of silver diffusion in silicon carbide, J. Nucl. Mater. 389 (2009) 326-331. 
doi:10.1016/j.jnucmat.2009.02.022.

[21] E. Friedland, N.G. Van Der Berg, J.B. Malherbe, J.J. Hancke, J. Barry, E. Wendler, W. Wesch, Investigation of silver and iodine transport through silicon carbide layers prepared for nuclear fuel element cladding, J. Nucl. Mater. 410 (2011) 24-31. doi:10.1016/j.jnucmat.2010.12.243.

[22] E. Lopez-Honorato, D.X. Yang, J. Tan, P.J. Meadows, P. Xiaow, Silver diffusion in coated fuel particles, J. Am. Ceram. Soc. 93 (2010) 3076-3079. doi:10.1111/j.1551-2916.2010.04055.x.

[23] T.T. Hlatshwayo, J.B. Malherbe, N.G. Van Der Berg, L.C. Prinsloo, A.J. Botha, E. Wendler, W. Wesch, Annealing of silver implanted $6 \mathrm{H}-\mathrm{SiC}$ and the diffusion of the silver, Nucl. Instruments Methods Phys. Res. Sect. B Beam Interact. with Mater. Atoms. 274 (2012) 120-125. doi:10.1016/j.nimb.2011.12.006.

[24] H.J. MacLean, R.G. Ballinger, L.E. Kolaya, S.A. Simonson, N. Lewis, M.E. Hanson, The effect of annealing at $1500{ }^{\circ} \mathrm{C}$ on migration and release of ion implanted silver in CVD silicon carbide, $\mathrm{J}$. Nucl. Mater. 357 (2006) 31-47. doi:10.1016/j.jnucmat.2006.05.043.

[25] H.Y. Xiao, Y. Zhang, L.L. Snead, V. Shutthanandan, H.Z. Xue, W.J. Weber, Near-surface and bulk behavior of Ag in SiC, J. Nucl. Mater. 420 (2012) 123-130. doi:10.1016/j.jnucmat.2011.09.028.

[26] W. Amian, D. Stöver, Diffusion of Silver and Cesium in Silicon-Carbide Coatings of Fuel Particles for High-Temperature Gas-Cooled Reactors, Nucl. Technol. 61 (1983) 475-486. doi:10.13182/NT61-475.

[27] D.A. Petti, J. Buongiorno, J.T. Maki, R.R. Hobbins, G.K. Miller, Key differences in the fabrication, irradiation and high temperature accident testing of US and German TRISO-coated particle fuel, and their implications on fuel performance, Nucl. Eng. Des. 222 (2003) 281-297. doi:10.1016/S0029-5493(03)00033-5.

[28] T.J. Gerczak, A.A. Campbell, J.D. Hunn, B.C. Jolly, A.T. Schumacher, R.L. Seibert, FY18Q3 Quarterly Report: Radiation Enhanced Diffusion of Ag, Ag-Pd, Eu , and $\mathrm{Sr}$ in Neutron Irradiated PyC / SiC Diffusion Couples, (2018).

[29] C.M. Petrie, Design and Thermal Analysis for Irradiation of Pyrolytic Carbon / Silicon Carbide Diffusion Couples in the High Flux Isotope Reactor, (2017).

[30] T.J. Gerczak, A.A. Campbell, J.D. Hunn, B.C. Jolly, A.T. Schumacher, Progress on Fabrication of Planar, Representative PyC / SiC Diffusion Couples, 2017.

[31] T.J. Gerczak, A.A. Campbell, J.D. Hunn, B.C. Jolly, A.T. Schumacher, FY18Q1 Quarterly Report : Radiation Enhanced Diffusion of Ag, Ag-Pd, Eu , and Sr in Neutron Irradiated PyC / SiC Diffusion Couples, 2018.

[32] T.J. Gerczak, A.A. Campbell, J.D. Hunn, B.C. Jolly, A.T. Schumacher, FY18Q2 Quarterly Report : Radiation Enhanced Diffusion of Ag, Ag-Pd, Eu, and $\mathrm{Sr}$ in Neutron Irradiated PyC / SiC Diffusion Couples, (2018).

[33] T.J. Gerczak, J.D. Hunn, B.C. Jolly, A.T. Schumacher, X. Hu, A.A. Campbell, J.A. Dyer, Development of Planar PyC / SiC Diffusion Couples to Investigate Irradiation Effects and Microstructural Variation on Fission Product Diffusion, (2018).

[34] T.J. Gerczak, J.D. Hunn, R.A. Lowden, T.R. Allen, SiC layer microstructure in AGR-1 and AGR2 TRISO fuel particles and the influence of its variation on the effective diffusion of key fission products, J. Nucl. Mater. 480 (2016). doi:10.1016/j.jnucmat.2016.08.011.

[35] S. Dwaraknath, G.S. Was, Development of a multi-layer diffusion couple to study fission product transport in $\beta$-SiC, J. Nucl. Mater. 444 (2014) 170-174. doi:10.1016/j.jnucmat.2013.09.040.

[36] S.S. Dwaraknath, G.S. Was, The diffusion of cesium, strontium, and europium in silicon carbide, J. Nucl. Mater. 476 (2016) 155-167. doi:10.1016/j.jnucmat.2016.04.034.

[37] J.D. Hunn, G.E. Jellison, R.A. Lowden, Increase in pyrolytic carbon optical anisotropy and density during processing of coated particle fuel due to heat treatment, J. Nucl. Mater. 374 (2008) 445452. doi:10.1016/j.jnucmat.2007.10.003.

[38] R.A. Lowden, Fabrication of Baseline and Variant Particle Fuel for AGR-1, Oak Ridge, 2006.

[39] C.M. Barnes, D.W. Marshall, B.L. Tomlin, J.T. Keeley, C.M. Barnes, Results of Tests to 
Demonstrate a Six-Inch - Diameter Coater for Production of TRISO- Coated Particles for Advanced Gas Reactor Experiments, (2008).

[40] J.W. Sterbentz, JMOCUP As-Run Daily Depletion Calculation for the AGR-1 Experiment in ATR B-10 Position, Idaho Falls, 2009.

[41] J.H. Miller, Methylsilane derived SiC particle coatings produced by fluid-bed chemcial vapor depostion, The University of Tennessee, 2006.

[42] A.G. Le Coq, K.D. Linton, R.C. Gallagher, T.J. Gerczak, K.A. Terrani, C.M. Petrie, Assembly of Rabbit Capsules for Irradiation of Pyrolytic Carbon / Silicon Carbide Diffusion Couples in the High Flux Isotope Reactor, (2018).

[43] A.A. Campbell, W.D. Porter, Y. Katoh, L.L. Snead, Method for analyzing passive silicon carbide thermometry with a continuous dilatometer to determine irradiation temperature, Nucl.

Instruments Methods Phys. Res. Sect. B Beam Interact. with Mater. Atoms. 370 (2016) 49-58. doi:10.1016/j.nimb.2016.01.005. 